\title{
The Ethics of Autonomy: Biography and the New Criticism
}

The New Critics gave poetry an independent status, liberating it from historical, biographical, and psychological requirements. They argued that the poem inhabits its own space, without support from either the author or the reader. This curious property is usually called "poetic autonomy," and historians of literary criticism generally note that the New Critics found the idea in Kant's Critique of Judgement. That Kant elsewhere defined the idea of autonomy in relation to human intention and freedom rarely figures as part of the story. Kantian ethics requires that human beings be treated as ends in themselves, as autonomous subjects, not as mere instruments to satisfy another's personal desires. In contrast, poetic autonomy is usually described in terms of the formal requirements of New Critical practice, and not as it relates to moral philosophy and human subjectivity. Two questions, then, arise for the ethics of criticism. Are there ethical motivations behind the shift from human autonomy to poetic autonomy, despite the New Critical disinterest in extrinsic issues? And to what extent, if any, does the idea of human autonomy secretly direct the character of the New Criticism?

Recently, Frank Lentricchia and Gerald Graff have argued that the aesthetic ideal of poetic autonomy prevents literary crit- 
ics from engaging in political and moral reform. The argument against the New Criticism's lack of social involvement turns most frequently on the issue of autonomy, but the ethical reasons behind the shift from human to poetic autonomy have received no sustained attention. The lack of interest may be related to the fact that recent critical theory also stresses a shift from the human to language. The poststructuralist theory of intertextuality challenges the autonomy of the lone poetic text, although not in a manner that dissents ultimately from the spirit of the New Criticism. The poststructuralists isolate language for study in the same way that the New Critics isolated the poem. For the poststructuralists, language is itself autonomous. The "death of man" leads to the question of language, just as the "death of the poet" led the New Criticism to the question of poetry. While disputing the privileged status of poetry, poststructuralism offers no serious threat to the doctrine of autonomy; it merely broadens its influence. Nor does it offer assistance in understanding the ethical basis of either poetic or linquistic autonomy.

In spite of its late theoretical formulation, the desire to escape the affective and intentional fallacies represents the essential impulse upon which the New Critical doctrine of autonomy rests. The fallacies fail to separate the concerns of the reader and the author from those of the poem, threatening in the New Critic's eyes to destroy the independence of poetic meaning. ${ }^{1}$

1. See the definitions of W. K. Wimsatt and Monroe C. Beardsley at the beginning of "The Affective Fallacy," in Wimsatt, The Verbal Icon (Lexington: University of Kentucky Press, 1954), p. 21. Frequently cited works will be noted parenthetically in the text. They include Monroe C. Beardsley, "Intention and Interpretations: A Fallacy Revisted," The Aesthetic Point of View (Ithaca: Cornell University Press, 1982), pp. 188-207; Ananda K. Coomaraswamy, "Intention," American Bookman 1.1 (1944): 41-48; T. S. Eliot, "Tradition and the Individual Talent," Selected Essays (New York: Harcourt, Brace, 1932), pp. 3-11; E. D. Hirsch, The Aims of Interpretation (Chicago: At the University Press, 1976) and Validity in Interpretation (New Haven: Yale University Press, 1976); W. K. Wimsatt and Monroe C. Beardsley, "Intention," Dictionary of World Literature, ed. Joseph T. Shipley (New York: Philosophical Library, 1943), pp. 326-29; W. K. Wimsatt, "Genesis: A Fallacy Revisted," in Issues in Contemporary Literary Criticism, ed. Gregory T. Polletta (Boston: Little, Brown, 1973), pp. 255-76; Wimsatt and Beardsley, "The Intentional Fallacy" and "The Affective Fallacy," in The Verbal Icon, pp. 3-18, 21-39. 
Wimsatt and Beardsley define the intentional fallacy as a confusion between the poem and its origins: it tries to derive a standard of criticism from the psychological causes of the poem, but ends in biography and relativism. They describe the affective fallacy as a confusion between the poem and its results: it tries to derive a standard of criticism from the psychological effects of the poem on the audience, but ends in impressionism and relativism.

The affective fallacy, however, has long lost the ability to intimidate the critical imagination. Theorists of reader response and of reception criticism thrive today in great numbers, attacking the prohibition against the affective fallacy from all sides. Jane Tompkins represents the essays in her Reader-Response Criticism as a direct assault on the New Criticism, and the volume attests to the significance that literary theory now accords to the reader. The resistance to the intentional fallacy, on the other hand, deserves to be called the defining feature of the New Criticism, and it has retained even today the force of a sacred taboo. The rejection of human intention remains for most critics, with the exception of E. D. Hirsch and a few others, a stable law of literary interpretation.

Intention, however, does not depend solely on questions of interpretation. The issue of intention represents one of the areas where the idea of the human as an ethical and anthropological category is most hotly contested by modern literary critics, and most often intention has survived as a theoretical principle only when it has been stripped of subjectivity. In American theory, for example, John Crowe Ransom, the most ontological of the New Critics, salvaged the idea of intention only by suggesting that poetry is directed by "poetic intentions." Separating the poet from intention, Ransom writes that the "total intention of the poem is something, but not an intention known to the poet at the moment when he begins to work up his logical content into a poem." 2 In phenomenology proper, this form of intention goes by the name of "intentionality." Maurice Merleau-Ponty,

2. John Crowe Ransom, The New Criticism (Norfolk, Conn.: New Directions, 1941), p. 224. 
Jean Starobinski, and the Geneva School in general redefine intention as a type of consciousness in language. Similarly, structuralist and poststructuralist theorists tend to empty intention of its human content. Edward Said defines intention as "an appetite at the beginning intellectually to do something," and "the net result is to understand language as an intentional structure signifying a series of displacements." 3 Finally, Paul de Man charts the enduring influence of the intentional fallacy on theory today when he argues that the structuralist critic strives to demonstrate the discrepancy between sign and meaning for the expressed purpose of eliminating the constitutive subject.

It was through the denial of intention, in fact, that the New Critics most forcefully maintained the rhetoric of the poem's autonomy, and the effect of that rhetoric remains a dominant force in theory to this day. Rightly or wrongly, the doctrine of the intentional fallacy has, in effect, forced critics to make a choice between human and poetic autonomy; and, as such, the idea of intention has a special importance for the ethics of criticism. This does not mean that a new argument for or against intention is necessary to address the ethics of the New Criticism or of literary criticism in general; the question of intention has a long history and will continue to be a major issue for many critics. Rather, it is a matter of reading anew the most significant discussions of intention in a manner that clarifies the relations among intention, autonomy, and the hidden ethical motivations of the critics in question.

\section{Against "Biographism"}

The pervasive use of such terms as "speaker," "narrator," and "persona" is generally considered to have emerged as a means of avoiding reference to the author's life and personality. Indeed, current narrative theory holds that all texts have narrators, and scholars from the most opposing camps now accept the critical use of such vocabulary as a caution against in-

3. Edward W. Said, Beginnings: Intention and Method (New York: Basic Books, 1975), pp. 12, 66. 
judicious identifications between an author and a text. Unfortunate is the uninitiated reader who dares to attribute a statement in a work to its author. Only if the attribution is too tempting to avoid may the clever theorist save face by accusing the writer of being too weak to hold a mask in place.

Critical doctrines often evolve in response to each other, and the popularity of the "persona" during high New Criticism aptly met the threat of the intentional fallacy. Indeed, Wimsatt calls the persona a "token of impersonality," impersonality being the "required condition for the kind of criticism that hopes to escape the 'intentional fallacy.' "4 Yet the use of such vocabulary may have had a related purpose now obscured by fifty years of formalism. Its appearance in critical discourse may protect poets from unfair identification with their characters and works. To assert that the New Critics were concerned with protecting poets, or concerned with them at all, may seem farfetched, but it opens the way to an unremarked dimension of the New Criticism. Poetic autonomy is not merely an aesthetic notion; it possesses an ethical dimension, for the separation that it creates between the poet and the poem acts to shield authors from aggressive criticisms.

"The Intentional Fallacy" by Wimsatt and Beardsley begins by attacking a paraphrase of the biographical critic's slogan: "In order to judge the poet's performance, we must know what he intended" (4). The "judicial" approach of the biographical theorist focuses on the poet with a critical eye, and the New Critics reacted to the tradition. ${ }^{5}$ Sainte-Beuve, for example, described authors in relation to their race, country, times, family, education, and environment, highlighting their associates, first suc-

4. W. K. Wimsatt, "Eliot's Weary Gestures of Dismissal," Massachusetts Review 7.3 (1966): 584-90, 585, and "Genesis: A Fallacy Revisted," p. 257.

5. See Stanley Edgar Hyman, The Armed Vision (New York: Knopf, 1948), pp. 11-12. Jacques Barzun, in "Biography and Criticism-a Misalliance Disputed," Critical Inquiry 1.3 (1975): 479-96, also touches without great emphasis on the accusatory dimension of biographical criticism. Frank Cioffi, "Intention and Interpretation in Criticism," in On Literary Intention, ed. David Newton-De Molina (Edinburgh: At the University Press, 1976), pp. 55-73, argues that Wimsatt and Beardsley mean biographical data when they refer to the design and intentions of the author and their relation to interpretation (50). 
cesses, and first moments of disintegration. He paid particular attention to the author's peculiarities of mind and body and placed special emphasis on weaknesses. Taine, Brandes, and Brunetière followed in the tradition, thereby institutionalizing the already long association between the work of art and the artist's irregularities. In Germany, there is a lengthy history of referring poetry to disease, and such writers as Goethe, Schopenhauer, Thomas Mann, and Nietzsche have related art to suffering and sickness. Freud forever established the special connection between the artist and illness by tracing the origin of art to neurosis, and once imported into literary criticism, psychoanalysis focused on the artist's weaknesses, producing the massive psychobiographies (of Poe, Goethe, and others) popular in the literary criticism of the middle twentieth century.

"Biographism," as the New Critics derisively called it, moves increasingly toward the idea that a writer's abnormality will be the major feature in determining the character of the poem. The natural outcome of such theories is a "judicial" criticism in which the poet is judged not merely for eccentricities but for a faulty character and criminal intentions. The opposition of the New Criticism to psychoanalysis, Marxism, and nineteenth-century biographical criticism in general derived from their enthusiastic identification of personality and poetry. ${ }^{6}$ We seldom remark that the New Criticism's antagonism constituted a genuine awareness of the accusatory dimensions of such identifications and as such concealed an ethical motivation in addition to the aesthetic ones normally associated with the movement. The moral thrust of the New Criticism against biographical criticism has become lost in the debate over how meaning is to be determined. But in fact the real source of dispute between New Critics and intentionalists was more ethical than semantic. The ideas of meaning held by the New Critics and the early intentionalists

6. Some of the strongest examples of biographical accusation appear in the age of the New Criticism. Van Wyck Brooks stresses the artist's personality or lack thereof and theorizes that the critic's selection of a topic is never accidental, but a secret confession of an affinity with the writer. Mark Van Doren tries to expel Whitman from the pantheon of democratic writers because of his homosexuality. 
were not so very different: both believed in one meaning for one text, and both poised themselves again and again against relativism.

\section{Poetic Execution}

An attack against biographical criticism similar to the New Critics' is captured in Benedetto Croce's critique of the notion that "the style is the man." It "seemed impossible," Croce explained, "that a man who gives expression to generous feelings should not be a noble and generous man in practical life; or that the dramatist whose plays are full of stabbing, should not himself have done a little stabbing in real life. Artists protest vainly: 'Lasciva est nobis pagina, vita proba.' They are merely taxed in addition with lying and hypocrisy." 7 That the style may be the author perpetuates the idea that poetic and real execution have qualities in common. If poets write about murder, apparently they are murderers-if not in reality, at least in intention. The biographical emphasis of psychoanalytic theory characteristically takes such tendencies to great extremes. In "Dostoevsky and Parricide," for example, Freud asks in a discussion of criminal behavior "why there is any temptation to reckon Dostoevsky among the criminals." "The answer is," Freud concluded, "that it comes from his choice of material, which singles out from all others violent, murderous and egoistic characters, thus pointing to the existence of similar tendencies within himself, and also from certain facts in his life, like his passion for gambling and his possible confession of a sexual assault upon a young girl" (178). ${ }^{8}$ When poets appear in biographical criticism, they appear to be attacked. The ethics of the New Criticism emerges in its denial of the identification between the author and poem. A formalist writing in another tradition, Roman Jakobson, attacked this identification with an analogy much in the spirit of the New Criticism. He maintained that "to incriminate the poet

7. Benedetto Croce, Aesthetics, trans. Douglas Ainslie (New York: Macmillan, 1922), p. 53.

8. See Sigmund Freud, "Dostoevsky and Parricide," The Standard Edition, ed. James Strachey, vol. 21 (London: Hogarth, 1961), pp. 171-96. 
with ideas and feelings" from his or her works "is just as absurd as the behavior of the medieval public which beat up the actor who played Judas." 9 The New Critics and Russian formalists both negated the role of the author, but only to preserve it, to protect authors from the violence of biographical criticism.

The New Critics opposed the notion that the critic is a judge imposing a sentence. The metaphor of the trial is hardly extraneous, for it recurs in both the New Criticism and biographical theory, suggesting a perceived association between literary intention and criminal guilt. In "Intention," the earliest sketch of the intentional fallacy, Wimsatt and Beardsley note that poets should not stand trial, but may be admitted as witnesses to meaning: "The author must be admitted as a witness to the meaning of his work, and one may even grant special validity to idiosyncratic associations of the author. .." (327). Later Wimsatt and Beardsley expand upon this idea, excluding it from the precinct of biographical criticism. They argue that the author's sense of a word contributes to the history of its meaning, not to biography, and must be studied in that light. Their objective, therefore, is not to estrange the author from the meaning of the poem but to eliminate the notion that meaning resides in authorial intention, a notion that retains a decidedly judicial coloring.

Intention is one of the major concepts of criminal justice. If we doubt that judicial and literary intention are related, we may simply recall the role of intention in those countries where political censorship rules. The preoccupation with the writer's ideology throughout the history of Russian literature represents a fine example of the ethico-political dimension of intention and its stake in political and critical violence. In "What Is an Author?" Michel Foucault defines the penal function of authorship in these very terms, remarking that "speeches and books were assigned real authors . . . only when the author became subject

9. Cited by Leon Trotsky, Literature and Revolution, trans. Rose Strunsky (Ann Arbor: University of Michigan Press, 1960), pp. 165-66. Trotsky objects to Jakobson's use of "incriminate," arguing that poets write in the language of their school and that poems involve a "complex system of psychological transmitting mechanisms in which there are individual, racial and social elements" (167). 
to punishment and to the extent that his discourse was considered transgressive" (124). ${ }^{10}$ The author-function in Foucault's view brings a false principle of coherence to the troublesome language of fiction. It tames the craft of lying and limits its hazards, but it accomplishes the task at the author's expense.

The metaphor of the trial emerges most dramatically in a critical response to the early dictionary article of Wimsatt and Beardsley. The response by Ananda K. Coomaraswamy in "Intention" comes to represent the idea of intention that Wimsatt and Beardsley most oppose in their late writings. Coomaraswamy claims in contradistinction to Wimsatt and Beardsley that criticism exists to find fault. "Criticism," he writes, "never presupposes that a work is faultless, and I say that we can never find fault unless we can distinguish what the author meant to say from what he actually said" (45). Finding fault with the poem soon leads criticism into the courtroom: "an evil intention need not result in a poor work of art; if it miscarries, it can be ridiculed or ignored; if it succeeds, the artist (whether a pornographer or a skilful murderer) is liable to punishment" (47). Although Coomaraswamy states that evil intentions need not result in poor literature, he immediately contradicts himself: evil intentions that fail should be mocked and those that succeed call for judicial action. The implication remains that good intentions determine good poetry, and if the poetry is not good, at least the poet's intentions should be. To lessen a charge or to acquit the poet standing trial for bad poetry, the critic, like the good lawyer, proves that the poet's intentions were at least innocent.

The New Critics were indeed the new apologists for poetry. Faced with the threat of judicial criticism, however, they became apologists for the poet. The insidious analogy between the expert murderer and the skillful poet figures in both the early and the late views of intention as conceived by Wimsatt and Beardsley, and it reveals that an ethical sensitivity to violence lurks beneath the debate over poetic autonomy. In "The Inten-

10. Michel Foucault, "What Is an Author?" in Language, Counter-Memory, Practice: Selected Essays and Interviews, ed. Donald F. Bouchard (Ithaca: Cornell University Press, 1977), pp. 113-38. 
tional Fallacy," they appear to confront the identification between murder and poetry, but actually use it as another occasion to reiterate their view of objective or artistic criticism. Astoundingly, they do not deny the analogy; rather, they work within it, providing the means to distinguish poetry from murder. To make this distinction, objective criticism asks whether the act (or poem) "ought ever to have been undertaken" and "whether it is worth preserving," not "whether the artist achieved his intentions" (5-6). The name "artistic criticism" is properly given to the inquiry that asks whether the work should be preserved. Ostensibly, Wimsatt and Beardsley think of judicial and literary intention as different species, but the apparent distinction actually conceals their fear of all forms of intention. Artistic criticism, they suppose, does not need a theory of intention; it judges the work itself. Judicial criticism, in contrast, has already passed judgment on the "work" and must determine the murderer's responsibility for his or her action. Whenever intentions are raised, Wimsatt and Beardsley fear, severe judgment of the poet follows.

Over twenty years later, the problem still haunts Wimsatt and Beardsley. In "Intention and Interpretation: A Fallacy Revived," Beardsley turns repeatedly to images of murder and lying. Specifically, he uses the example of accusation to define intention, and illustrates his discussion of how intention relates to failed performative gestures with the case of firing a gun and missing the target. In "Genesis: A Fallacy Revisted," Wimsatt argues that "we may indeed be likely to assign a kind of merit" to the successfully planned and executed murder, "but it should be understood as referring to the artist himself (who was 'skillful' enough to do what he aimed at doing) rather than to the workwhich may be a murder, a robbery, a libel, a silly lampoon" (266). Still trying to separate themselves from the intentionalists, Wimsatt and Beardsley nearly fall into their camp. Now a skillful murderer is an agent whose intentions and deeds correspond. Their position rediscovers that of the intentionalist critic who argues that "we can never find fault unless we distinguish what the author meant to say from what he actually said."

The response of Wimsatt and Beardsley to the metaphor of 
the skillful murderer reveals a lapse in their argument, although it does not represent a complete acceptance of intention. Judicial intention is arguably as complex as literary intention, but Wimsatt and Beardsley separate them with little effort. The New Critics simply cannot dispose of intention in the case of murder because social responsibility is at issue. Poetry, after all, is not murder, even though some critics treat bad poets like assassins. Morse Peckham similarly notes that Wimsatt and Beardsley have different theories of intention for poetic and ordinary language: in ordinary language, unlike poetry, intention determines meanings $(141-42) .{ }^{11}$ These two slips have no impact on New Critical practice, but they do expose the limits of its antiintentionalism and its preoccupation with ethics.

Yet a major difference remains between the intentionalist and the New Critic. Whereas the intentionalist trusts the statements of authors, Wimsatt and the New Critics remain skeptical. Wimsatt claims, first, that it is not feasible "to illustrate all kinds of evidence (or supposed evidence) that may be adduced from an author's plan outside the poem." Second, he denies that the critic can trust statements of intention: "when does the witness mean what he says?" Furthermore, in the case of poetry, unlike that of murder, it must be determined whether statements of intention were written before or after the poem, or whether "testimonies written before the poem might well have suffered by change of intention while the poem was being written." Wimsatt's vocabulary-"evidence," "witness," and "testimony"-implies that the New Critic has not yet left the courtroom of judicial criticism, but his refusal to condemn even the "skillful murderer" betrays a reluctance to sit in judgment of the poet ("Genesis" 266).

"Genesis" finally makes clear Wimsatt's distinction between the "biographical" and the "objective" critic. The biographically oriented critic "will find a correspondence between life and work an explanation of either goodness or badness in the work, as he happens to find the work itself good or bad" (260). In

11. Morse Peckham, "The Intentional? Fallacy?" in On Literary Intention, ed. Newton-De Molina, pp. 139-57. 
short, the biographical critic blames the poet's life for the quality of the poem. Contrariwise, Wimsatt's objective critic learns "to discipline his efforts unless he wishes to surrender to the flux, the gossip, the muddle and the 'motley' "for which the biographical critic so earnestly yearns (275). Objective criticism, in Wimsatt's view, cannot rely on gossip and accusation.

The New Critics clearly saw intentionalism as a species of gossip and consequently referred the intentional fallacy to the Romantic conception of the poet. Romantic artists sacrificed themselves on the altar of beauty and poetry, laying claims to extraordinary sensitivity and intuitions. Their passwords were "spontaneity," "originality," "individuality," and "feeling." In Romanticism, personality became the greatest work of art, and the cult of the poet came into prominence. According to Wimsatt and Beardsley, the intentional fallacy unwittingly participates in Romantic "bardolatry," whereas the New Critical doctrine of poetic autonomy refuses it. Nevertheless, the New Critics never stopped defending the poet. Herein lies the essential quandary of the New Criticism: to oppose bardolatry, but to defend the poet-all without falling with an embarrassing crash between the two chairs.

The quandary is genuine and reappears in different guises. The New Critics, for example, deal roughly with the critics who try to appropriate poems for their own. It is not unusual to find the New Critics attacking an idiosyncratic or highly individualistic critical reading, and by today's standards the New Criticism appears quite conservative. Yet they did not agree with those who would defend against aggressive misreadings by taking recourse to authorial meaning. "The poem," argue Wimsatt and Beardsley in their famous article, "is not the critic's own and not the author's (it is detached from the author at birth and goes about the world beyond his power to intend about it or control it). The poem belongs to the public. It is embodied in language, the peculiar possession of the public, and it is about the human being, an object of public knowledge" (5). Even "a short lyric poem is dramatic, the response of a speaker (no matter how abstractly conceived) to a situation (no matter now universalized). We ought to impute the thoughts and attitudes of a 
poem immediately to the dramatic speaker, and if to the author at all, only by an act of biographical inference" (5). The idea of the speaker, however, merely embraces the contradictions of the New Criticism. It saves the author from criticism, but places language in the service of the human subject. It makes poetry impersonal and personal at the same time.

The New Critical view of inspiration pivots on a similar contradiction. The New Critics attacked the Romantic concept of inspiration, but they asserted that everyday language is more abstract than poetry, for poetry conveys meaning ontologically and sensuously: "A poem should not mean but be." They refused to relinquish the special status of poetry and poetic inspiration. Wimsatt and Beardsley turn to Plato's famous attack on poetic inspiration to condemn Romantic bardolatry, but they end by admitting that Socrates "saw a truth about the poetic mind which the world no longer commonly sees-so much criticism, and that the most inspirational and most affectionately remembered, has proceeded from the poets themselves" (7). On the one hand, they praise the message of the poet as more exciting than the critic's, although they doubt its validity. On the other hand, they admit that tranquillity inspires poetic expression, whereas scholarship does not, and criticize Eliot and modern poets in general for reading and planning too much. The New Critics differed from Plato in the final analysis. They did not wish to expel the poets from the state. They preferred to direct criticism away from them. Yet poets were still inspirational, if not in Plato's sense, at least in a modern one. Although the New Critics sometimes affirmed the poetic quality of the critical act, they nevertheless preserved the privileged status of poetry and its traditional primacy over literary criticism. Simply put, the "judgment of poems is different from the art of producing them" (9). When Wimsatt and Beardsley conclude "The Intentional Fallacy" with the ironic caveat, "critical inquiries are not settled by consulting the oracle," we understand that they are placing to rest bardolatry and the intentional fallacy, but less completely than they may have wished. Ironically speaking or not, they still attribute to the poet the inspirational power of the oracle. 


\section{Impersonal Poetry}

The New Critics formed strong alliances with modern poets, and it may seem especially odd that so many poets joined the critical movement generally held responsible for removing the poet from center stage. Yet the poets themselves expressed the wish to escape the focus of criticism. Sketching the doctrine of autonomy that Wimsatt and Beardsley were later to institutionalize, T. S. Eliot argues in "Tradition and the Individual Talent" that "to divert interest from the poet is a laudable aim: for it would conduce to a juster estimation of actual poetry, good and bad" (11). Ransom, the poet and New Critic, agrees with Eliot and describes his theory of poetry with the notorious word "autotelic," thereby establishing the standard for the New Critical doctrine of autonomy. He also calls Eliot a "historical critic," but not to situate him among the historical and biographical thinkers whom the New Critics detested. Whereas Eliot is a "historical critic," the members of the old guard are "historical scholars."

Ransom has in mind Eliot's notion of tradition and the individual talent, a theory that displays the New Criticism's characteristic ambivalence toward the poet. Not surprisingly, Eliot's view of impersonality and tradition, like the intentional fallacy, both negates and celebrates the poet. He theorizes that great poets possess a historical sense not only of the pastness of the past but of its presence as well. They write not with their own generation in mind but with the whole of literature before their eyes. In the poet's mind, the whole of literature has a simultaneous existence and order that permit artists to be aware of both their place in time and their contemporaneity. Thus, poetic impersonality lessens the particular achievements of individual periods, poets, and poems by enmeshing them in a great weave of textuality, for Eliot defines "poetry as a living whole of all the poetry that has ever been written" (7). But we have not yet arrived at the poststructuralist theory of intertextuality, which describes a text not as a unified writing but as a set of relations with other texts, that is, as a fragmentary set of voluntary and involuntary borrowings. The poststructuralists attribute the 
workings of intertextuality to writing itself, whereas Eliot submits that the substance of tradition is melded through the catalytic power of the poet's mind.

The talented poetic mind sublimates itself in the tradition. Like Wimsatt and Beardsley, Eliot struggles to define poetry without making recourse to the poet's personality. He claims that his denial of the poet is a reaction against the Romantic cult of personality that was responsible in part for the growth of biographical criticism. Nevertheless, Eliot's descriptions of poetic impersonality take many motifs from Romanticism, especially its ideals of sacrifice and suffering: "The progress of an artist is a continual self-sacrifice, a continual extinction of personality" (7). Eliot seems to underestimate the extent to which the rhetoric of self-sacrifice contributes to the Romantic cult of the poet, as any careful look at the lives of the great Romantic writers will demonstrate. Michel Foucault, on the contrary, gives special status to the sacrificial character of authorship. In his view, the defining feature of authorship from Flaubert to Kafka is the link between writing and sacrifice. Modern works of art, Foucault explains, are born by murdering their authors, and authors represent themselves as the victims of their own writing. The death of the author has as an immediate result the questioning of the unity of the literary work, which prepares the scene for the arrival of the theory of intertextuality.

Eliot's concept of self-sacrifice pivots on an ambivalent view of the poet. The more perfect the artist, the more completely separate in the poem will be the person who suffers and the mind that creates. Eliot dares to argue that what matters to poetry is not the intensity of emotions but the pressure under which fusion between poetry and emotion takes place in the poet's mind. As "mind" replaces "poet," Eliot's theory of impersonality emerges. The poet does not express personality in the Romantic tradition. Rather, the poet is a "medium," in which "impressions and experience combine in peculiar and unexpected ways" (9). Eliot still accents peculiarity, but he expects that novelty will somehow emerge without casting its light of strangeness on the writer. The poet's mind here is not the celebrated filament of platinum but some type of alchemical vessel, a caldron from 
which poetry boils. Eliot seems to exclude the poet from his description of mind, but the concept of inspiration lingers in his metaphors. Even though he specifically opposes the Romantic view of poetry as a spontaneous overflow of emotion, the alchemical images reintroduce it. Finally, in Eliot's most celebrated description of poetry, the poet continues in the Romantic tradition to occupy center stage, although the role is expressed obliquely. Like the critic, the poet directs attention away from the poet toward poetry: "Poetry is not a turning loose of emotion, but an escape from emotion; it is not the expression of personality, but an escape from personality." The ideal of selfsacrifice reaches perfection, but the poets remain in power, for only they have the need and will to sacrifice themselves. Poetry is an escape from personality, Eliot explains, "but, of course, only those who have personality and emotion know what it means to want to escape from these things" (10-11).

If the emotion of art is truly impersonal, why does Eliot preoccupy himself with the poet's personal sacrifices and sorrows? Wimsatt argues that Eliot views suffering as indispensable to poetry, despite the doctrine of impersonality, and notes that "few poets have been treated less impersonally" than Eliot ("Eliot's Weary Gestures" 585). Moreover, few poets express themselves less impersonally. As Eliot transforms the Romantic cult of personality into a cult of personal impersonality, it grows apparent that impersonality serves merely as a mask to preserve personality. Only the poet who has personality knows to seek the security of impersonality. No matter how strongly Eliot asserts the doctrine of impersonality, personality returns like a bad dream, and no doubt with its bad dreams. In a word, Eliot defines personality as that which tries to escape personality. To arrive at the Romantic view of personality, we need only substitute "personality" for "progress" in his phrase "The progress of an artist is a continual self-sacrifice, a continual extinction of personality."

Eliot's early denial of personality prepares for its overt return in his late writings. In "Impersonality in Blanchot," Paul de Man reminds us that the askesis of depersonalization in Blanchot, which conceives of the work as an autonomous unity, prepares 
the way for the reappearance of subjectivity, which has never in fact ceased to be present. ${ }^{12}$ Similarly, personality never disappears in Eliot; it merely moves underground for shelter. As a rule, the interplay between personality and impersonality serves a protective function. It only remains to ask what poets seek protection from, and the answer surfaces in Eliot's earliest formulation of poetic autonomy. Poetic autonomy guarantees poetic anonymity, and anonymity remains the best defense against the animosity of biographical criticism and the gossip of the press: "Honest criticism and sensitive appreciation are directed not upon the poet but upon poetry. If we attend to the confused cries of the newspaper critics and the susurrus of popular repetition that follows, we shall hear the names of poets in great numbers; if we seek not Blue-book knowledge but the enjoyment of poetry, and ask for a poem, we shall seldom find it" $^{\prime \prime}(7) \cdot{ }^{13}$

\section{The New Intentionalists}

The New Critics deplored the aggressive instincts of biographical and intentionalist theory, and this ethical thrust combined with their strong literary interest in poetry to direct criticism away from the author and toward the work. Although some forms of biographical criticism may indeed treat the author unkindly, it is nevertheless unwise to accept the New Critical rejection of intention merely for ethical reasons, for intentionalist theory also possesses ethical hopes. Here the recent writings of E. D. Hirsch provide a fine counterexample to the New Critical view of intention, since they privilege with unabashed zeal the role of ethics in interpretation. Hirsch argues that authorial

12. Paul de Man, "Impersonality in the Criticism of Maurice Blanchot," Blindness and Insight (1971; reprint, Minneapolis: University of Minnesota Press, 1983), pp. 60-78.

13. On the motivations for impersonality, see "Interview with Harold Bloom," Diacritics 13.3 (1983): 57-68, where Bloom remarks that Eliot's statement about the impersonalized role of poets is "a self-serving defense," but one directed against his poetic precursors and not against the academic attitude toward poets. 
intention is the best standard for validity in interpretation not because original meaning is most valid, but because it represents an ethically superior choice for the critic. The moral imperative of language demands that the critic "respect an author's intention," which explains "why, in ethical terms, original meaning is the 'best meaning'" (Aims of Interpretation 92). Hirsch's theories openly challenge the New Critical doctrine opposing the intentional fallacy. Yet his style and manner often recall those of the New Critics, and for all his polemics, he never makes a direct frontal assault on Wimsatt and Beardsley. When their names arise, his criticisms soften. Indeed, Validity in Interpretation, the book in which he argues the case for authorial intention, is dedicated to Ronald S. Crane and William K. Wimsatt. Intentionalist theory and the New Criticism make strange bedfellows, but given that Hirsch enjoys disclosing areas of agreement shared by apparently opposing theories, perhaps he has found common ground for friendship. In fact, in their concern with ethics, the New Critics and the new intentionalists are brothers under the skin.

Hirsch is admirably frank on the issue of ethics in interpretation. In The Aims of Interpretation, he supplies the ethical dimension missing from his argument in Validity in Interpretation, transposing the ethics of language into a golden rule of critical interpretation. Critics must not disregard the original intentions of writers, he insists, if they wish their own intentions to be honored. Hirsch bases the golden rule on a general maxim of ethical behavior, advising that individuals treat each other equally. "When we simply use an author's words for our own purposes," he writes, "without respecting his intention, we transgress . . . 'the ethics of language,' just as we transgress ethical norms when we use another person merely for our own ends" (90). Hirsch concludes that individuals should be conceived as "ends in themselves" and not as instruments of others. By refusing to admit the intentions of an author's words, the critic loses the "soul of speech" and succumbs to a form of interpersonal violence. "To treat an author's words," Hirsch explains, "merely as grist for one's mill is ethically analogous to using another man 
merely for one's own purposes" (91). ${ }^{14}$ In this light, the New Critical denial of intention appears particularly ruthless, as ruthless, I suspect, as biographism seems to the New Critics.

It is clear that Hirsch views the critic's appropriation of the author's meaning as a perverse act of will, and he tries to subvert New Critical anti-intentionalism largely through the rejection of poetic autonomy. Autonomy, for Hirsch, is not a formalistic idea but part of a program of evaluation based on intrinsic categories. The New Critics feared that literature would lose its essential character when viewed in historical and biographical contexts. As a consequence, Hirsch argues, they developed categories especially appropriate to literature. Poetic autonomy strives to represent literature as literature and not as an instrument for historical and psychological documentation. It is clear that Hirsch, although atuned to ethical issues, views the New Criticism as merely an aesthetic movement. For Hirsch, the New Critics showed no desire to protect poets, and he finds the aesthetic doctrine of autonomy to be inadequate, skeptically inquiring, "what lies behind tautological formulations like the injunction to consider a poem as a poem?" (129).

Hirsch discovers the origin of poetic autonomy and the literary study of literature in the Romantic period. Wimsatt and Beardsley similarly argue that the intentional fallacy and bardolatry are Romantic inventions. Whereas Wimsatt and Beardsley make Romanticism responsible for the disappearance of poetic autonomy in criticism, Hirsch holds Romanticism responsible for its appearance and proliferation. More specifically, Hirsch claims that the Romantics mistakenly created an ethic of individuality to preserve the sovereignty of the particular from the domination of the general. As each culture becomes a note in the divine symphony, the ideal of cultural relativism emerges, and to preserve pluralism, each individual, culture, and text must be judged in its specificity.

Can Romanticism be responsible for both the decline and the

14. Cf. Jack Meiland, "Interpretation as a Cognitive Discipline," Philosophy and Literature 2.1 (1978): 23-45. Meiland objects that using a work of art for purposes other than those the author intended does not infringe upon his or her individual freedom, since that freedom was exercised in the creation of the work. 
rise of autonomy as a standard of criticism? The defining ethic of Romanticism, from Rousseau through Kant to its modern equivalents, is the preservation of equality over the human impulse to judge individual differences as the proof of inequality. The Romantic idea of individuality represents each person and object as individual unto itself, but maintains as well that all are equal in their individuality. Despite their idea of equality, however, the Romantics placed the greatest stress on individuality, and cults of the individual sprang forth as a result. But there can be cults of individuality for both authors and texts. The New Criticism struggled to protect the individuality of the poem and denigrated the presentation of an author's individuality as bardolatry. The new intentionalism strives to preserve the individuality of the author and disdains the cult of art for art's sake.

Both criticisms derive their principles from the Romantic ideal of sovereign individuality. And it is no coincidence that Hirsch has recourse to Kant (and the Nicomachean Ethics) in order to formulate his golden rule of criticism. Acknowledging the influence of his teacher John Crowe Ransom, Allen Tate also describes his critical education as a composite of "Kantian aesthetics and a philosophy of dualism, tinged with Christian theology, but ultimately derived from the Nicomachean ethics" (616). ${ }^{15}$ The principle of autonomy lies beneath both positions. By autonomy, I mean that an author or poem is its own instrument and not that of another writer or discourse. Autonomy in its purest form is not necessarily a sound philosophical principle. It is an ethical ideal, an ideal discovered by Romanticism, compatible with cultural and critical relativism, but incompatible with collective and normative enterprises, whether social or linguistic. Individuals cannot act by their own rules in society any more than speakers can speak by their own rules in language. There must be a system of mutual definition between the particular

15. Cited by Russell Fraser, "My Two Masters," Sewanee Review 91.4 (1983): 614-33. Fraser also captures the New Critical position on biography: "All roads led back to form. The academic community denied this, and dissolved the poem into biography and history. It offered a pretext for the study of the sexual life of the poet, maybe of the reader, or of anything else that Professor $X$, pursuing his own vagaries, wanted to study" (632). 
and the general. Consequently, Kant, unlike Rousseau, seeks to preserve order by placing certain restrictions on individual freedom. The autonomy of individuals is sacred only on the condition that they respect the autonomy of others.

Frank Lentricchia, in After the New Criticism, remarks that the doctrine of poetic autonomy held by Northrop Frye and the New Critics would be unimaginable without Kant. In The Aims of Interpretation, Hirsch refers specifically to Kant to establish the ethical ideal that individuals should be conceived as ends in themselves. The primary issue is whether and how these two forms of autonomy relate. Hirsch's attack on the politics of the New Criticism introduces a context in which the connection between poetic and human autonomy is dramatically exposed. He contends that the superiority of the New Criticism in the public mind springs only from the privileged ring of its rhetoric; and to debunk the myth of the poem in itself, he compares it to the myth of man as the privileged category: "The 'literary study of literature' has a privileged ring to it, like 'the proper study of mankind is man' " (129). Hirsch's debunking of the ideal of "literature as literature" depends in part on the New Critical and structuralist debunking of "man as man," and it brings him into his opponents' camp. He means to deflate the New Criticism with the comparison, but risks undermining his argument for authorial intention. The main support for the superiority of authorial intention is Hirsch's ethical requirement that all people be recognized as unique and autonomous on the basis of their shared humanity. If he attacks the status of autonomy in the New Criticism, it cannot stand within his own work.

Hirsch's comparison is possible only because the New Critics and intentionalists converge on the issue of autonomy. Indeed, Hirsch discovers the equation whereby formalist critics replace "man" with "literature" and maintain for poetry the special status of human autonomy. But Hirsch misses the opportunity to enter the New Criticism's secret home of subjectivity. He fails to understand that the real reason for the New Critic's love of poetic autonomy is not the preservation of aestheticism but the protection of individuality, whether in the form of the poet or of the poem. Instead, he advances the explanation that the Popean 
injunction to study literature as literature conceals the aesthete's conflation of art and literature, whereas literature in fact cannot be privileged as a linguistic act. In Hirsch's opinion, "literature has no independent essence, aesthetic or otherwise. It is an arbitrary classification of linguistic works which do not exhibit common distinctive traits, and which cannot be defined as an Aristotelian species" (135). Hirsch's attack on "literature" sounds remarkably like Foucault's attack on the "author." "Literature" and "author" are viewed by Hirsch and Foucault respectively as false unities that distort their objects by representing them as essentialistic. "No critical approach can," Hirsch writes, "without distortion, make essentialistic claims upon literature" (135). Nor can a critical approach make essentialistic claims upon an author without risking distortion, which explains why the New Critics reject the two extremes of biographical theory: judicial criticism and bardolatry.

The battle cry "autonomy" permits any poem to enter the canon of literature because any poem can be established if it is judged intrinsically according to its own categories; and Hirsch worries that the literary study of literature will pervert ethical and aesthetic principles. ${ }^{16}$ The ideal of autonomy may be held responsible for the perversion of standards because it risks separating literature from life, but it also depends on an ethical motivation. Hirsch, whose main interest lies with ethics, might be expected to understand what is at stake. Just as bardolatry and anonymity allow poets to transgress normative standards and to infuse poetry with individuality, the principle "literature" places texts beyond the reach of criticism and frees the individualizing impulses of writers and critics. The battle cry "autonomy" transforms the domain of literature into an island, like

16. The heterogeneity of the literary curriculum in American universities, which includes such course titles as "The Literature of Fantasy," "The Black Man in Literature," "Women in Literature," and "Patristic Elements in Anglo-Saxon Literature," provides Hirsch with an example of such perversions. The term "literature" in such titles is for him a "mere concession to academic propriety," and his rejection of them is ethically disturbing within the context of his ethical quest. The titles can indeed be explained by the principle of autonomy, but they also reveal the ethical foundation of critical relativism. See Aims of Interpretation, p. 136. 
Rousseau's Saint-Pierre, made safe for the poet. "Literature" is an ethical category, an invention of Romantic ideals used to protect the integrity and particularity of authors and works against colonization by politics, mores, and alien ideologies in general. Thus the Chicago critic R. S. Crane, although suspicious of the New Criticism, could write in defense of poetic autonomy that "no literary work is other than it is or better or worse than it is because of any circumstances of its origins or of any personal peculiarities of its author or of any filiation that it may have with other works or of any reflection in it of the philosophical doctrines or the economic interests of its age" (658). ${ }^{17}$ In short, Crane claims that the knowledge of authors should not bias criticism against their work but should serve to eliminate prejudice and to preserve diversity. The ideal of poetic autonomy is fused inextricably with the ethics of human autonomy.

Literary criticism preserves, more often than not, the hesitations surrounding the judgment and condemnation of human beings, and if critics forget their relation to the human world, they risk misunderstanding the nature of their own judgments. A startling example has recently emerged. In their argument against theory, Steven Knapp and Walter Benn Michaels define theory as the supposition that literature is free of intention and assert that meanings without intentions are meaningless as well. Knapp and Michaels are correct in their assertions, but they obey the same inclinations as those whom they attack. A clearer way of making this argument would be to define theory as the belief that literature can be other than a human creation. But anthropological concepts remain so unfashionable at the present time that most critics avoid them even at the expense of clarity. ${ }^{18}$

Both the New Critics and the intentionalists fall into this trap, endangering the bond between literature and life. In Hirsch's case, the idea of the human acts to exclude the idea of literature;

17. Ronald S. Crane, "History versus Criticism in the University Study of Literature," English Journal 24, College Edition (1935): 645-67.

18. Steven Knapp and Walter Benn Michaels, "Against Theory," Critical Inquiry 8.4 (1982): 723-42. 
his admirable desire to protect the rights of authors leads him to treat works of literature as if they were people. But reading a work incorrectly is not like misinterpreting a person, as long as a critical misinterpretation does not become the basis for unfair judgment and violence. Authorial autonomy is best exercised in the creation of a work and not in the writings of critics. In the final analysis, Hirsch takes a Platonic and marginal view of literary meaning. He decides to reject "literature" in favor of "the human" and ends by making the interpretation of poetry a risky enterprise at best for the ethically minded.

The New Criticism falters as well because it substitutes "literature" for "the human" in a way that banishes the human subject in the very act of protecting it. New Critical theory tries to dispense with human intentions, but it ends by giving language the multiple and human character of being. Indeed, the ontological characteristics of poetry were so strong for the New Critics that any attempt to reduce the language of paradox to facts or statements risked destroying the "life" of the poem, and such fears soon turned the New Criticism against its own method of close reading. The New Critics believed that it is impossible, without committing an act of violation, to paraphrase a poem, but all criticism is by definition a form of paraphrase. Cleanth Brooks's "The Heresy of Paraphrase" states the issue clearly. The essay begins by attempting to place the individual poem or poetry in general within an inviolable domain of signification, but it is only a short step to the position that all criticism perpetuates violence against poetry. "If we allow ourselves to be misled by the heresy of paraphrase," Brooks cautions, "we run the risk of doing even more violence to the internal order of the poem itself" (202). ${ }^{19}$ Brooks ends by arguing for the need to protect poetic language from critical violence, much as Hirsch and the new intentionalists argue for the need to preserve the author's meaning from aggression.

The New Critics and intentionalists are both ethical in principle, despite their apparent differences, because they desire to

19. Cleanth Brooks, "The Heresy of Paraphrase," The Well Wrought Urn (New York: Harvest Books, 1947), pp. 192-214. 
free criticism from violence. Each prefers to choose freedom over aggression. Indeed, the embrace of autonomy, whether concerned with the author or the work, reveals a more than tacit awareness of the role played by human conflict in the creation of meaning and the writing of criticism, and such awareness is the mandatory first step for an ethics of criticism. But the knowledge of violence will have no meaning for any school of criticism if it has only words to save. The ethics of criticism cannot endure when it abandons the world of human meaning and questioning. Literary criticism, as the New Critics understood, needs a theory of language, but no viable theory of language can exist in the absence of a human ethics. Both the New Criticism and the new intentionalism try to divide literature and the human to avoid the violence of their own criticisms. But ultimately neither one can really separate ethics from criticism or the question of the human from that of literature. For "all questions," even W. $\mathrm{K}$. Wimsatt has to admit, "lead to the master question, 'What is Man?'"20

20. Wimsatt, "Eliot's Weary Gestures," p. 588. 